\title{
Small-scale diversity of plant communities and distribution of species niches on a copper rock outcrop in Upper Katanga, D.R.Congo
}

\author{
Edouard Ilunga wa Ilunga, ${ }^{1,2}$, Maxime Séleck², Gilles Colinet ${ }^{3}$, \\ Michel-Pierre Faucon ${ }^{4}$, Pierre Meerts ${ }^{5}$ \& Grégory Mahy ${ }^{2}$
}

\begin{abstract}
${ }^{1}$ Université de Lubumbashi, Faculté des Sciences Agronomiques, Lubumbashi, Democratic Republic of Congo
${ }^{2}$ Departement of Forest, Nature and Landscape, Biodiversity and Landscape Unit, Gembloux Agro-Bio Tech, University of Liège, 2 Passage des Déportés, BE-5030 Gembloux, Belgium

${ }^{3}$ Department of Science and Environmental Technology, Soil \& Water Systems Unit, Gembloux Agro-Bio Tech, University of Liège, 2 Passage des Déportés, BE-5030 Gembloux, Belgium

${ }^{4} \mathrm{HYdrISE}$ (Hydrogeochemistry Interactions Soil Environment) unit, Institut Polytechnique LaSalle Beauvais (ISAB-IGAL), 15 rue Pierre Waguet, FR-60026 Beauvais, France

${ }^{5}$ Laboratory of Plant Ecology and Biogeochemistry, Université Libre de Bruxelles, 50 Avenue F. Roosevelt, BE-1150 Brussels, Belgium

*Author for correspondence: ilungaedouard@gmail.com
\end{abstract}

\begin{abstract}
Background and aims - In Katanga (D.R.Congo), outcrops of bedrocks naturally enriched in $\mathrm{Cu}$ and Co ("copper hills"), host unique plant communities. The spatial variation of vegetation has long been attributed almost exclusively to variation in $\mathrm{Cu}$ concentration in the soil, but this assumption has not been experimentally tested. We analysed the variation in plant communities and the niches of selected species in relation to edaphic factors within a copper hill.

Methods - Forty-eight $1 \mathrm{~m}^{2}$ plots were sampled for plant community and soil mineral element composition, and classified with Unweighted Pair Group Method with Arithmetic mean (UPGMA) using the Bray-Curtis distance. Plant-edaphic relationships were examined using a Canonical Correspondence Analysis (CCA). Species niches were modelled with Generalized Additive Model (GAM). Mean edaphic factors between the soil of plant communities were compared with one-way Kruskal-Wallis non-parametric ANOVA.

Key results - The diversity of communities at the site scale was higher than observed in previous studies at a larger scale. $\mathrm{Cu}$ was the most discriminating edaphic factor of plant communities. However, detailed comparisons of mean edaphic factors among communities revealed individual combinations of edaphic parameters for each community, as well as differences in soil $\mathrm{Cu}$ content. High covariation appears to be an essential trait of the edaphic factor variation of Katangan $\mathrm{Cu}$-rich soils. This makes it difficult to examine separately the effect of these factors on plant community structures. A bimodal pattern of niche distribution was found for $\mathrm{Cu}$ and $\mathrm{pH}$. For physical parameters, niche optima were normally distributed.

Conclusions - Global variation in edaphic factors associated with variation in combinations of edaphic parameters generates a highly heterogeneous environment favourable to a high diversity of plant communities over limited areas. Conservation strategies or restoration actions to limit the impact of mining activities on $\mathrm{Cu}$-enriched ecosystems should pay special attention to recreate heterogeneity, taking into account the covariation of edaphic factors.
\end{abstract}

Key words - conservation, copper, ecological niche, heavy metals, mining activities, plant community, vegetation.

\section{INTRODUCTION}

Identification of the factors that control the distribution and abundance of plant communities is a central problem in ecology, which can be addressed at all spatial scales, ranging from continental scales to patchy or highly restricted mi- crohabitats (Keddy 2007). The problem of plant community variation is more often assessed over a large scale, encompassing obvious environmental gradients or patchy heterogeneity. However, it is clear that environments can also vary over very small spatial scales and this small-scale variation directly impacts on plant assemblages (Odum 1988, Vivian- 
Smith 1997, Grace et al. 2011). Among the factors that are main contributors to the diversity and distribution of plant communities, edaphic conditions are of primary importance, whether they influence plant communities through resource availability, water stress or toxicity stress. From all the chemical edaphic factors that might influence plant assemblages, heavy metals have a long history of interest. Throughout the world, metal-rich soils host highly distinctive plant communities that result from deterministic species selection by environmental filters and random processes in insular habitats (Ernst 1974, Kruckeberg 1984, Bergmeier et al. 2009, Bes et al. 2010, Saad et al. 2012). Due to the severe selection pressure resulting from metal toxicity, they also offer outstanding examples of microevolution and speciation processes and very often host rare endemic taxa adapted to elevated concentrations of heavy metals (Antonovics et al. 1971, Brooks et al. 1982, Rajakaruna 2004, Faucon et al. 2010, Harrison $\&$ Rajakaruna 2011). Small scale variation in edaphic conditions in metalliferous sites have been demonstrated to affect physiological and evolutionary process (Malaisse et al. 1983, Bizoux et al. 2008, O’Dell \& Rajakaruna 2011, Yost et al. 2012), species distribution (Rajakaruna 2004) and, ultimately, variation in plant assemblages (Ernst 1974, Bizoux et al. 2004, Tsiripidis et al. 2010).

Throughout the world, the flora of metalliferous soils is threatened by human activity and actions aimed at preserving metallophyte species are imperative (Whiting et al. 2004). Designing conservation and rehabilitation programmes, including restoration of habitats, is urgently needed, to limit the extinction risk of metallophyte plants and ecosystem loss (Whiting et al. 2004, ICMM 2006). Such a strategy relies on a sound understanding of the ecological niche of the target species and of factors that determine plant community composition at different spatial scales (Whiting et al. 2004, Chipeng et al. 2010, Faucon et al. 2012a).

Katanga (D.R.Congo) and adjacent areas of Zambia host one of the world's largest concentrations of $\mathrm{Cu}-\mathrm{Co}$ deposits (Yoshida et al. 2004, Cailteux et al. 2005). Outcrops of bedrocks naturally enriched in $\mathrm{Cu}$ and $\mathrm{Co}$, host highly original herbaceous plant communities, which sharply contrast with those of the surrounding forest (Duvigneaud 1958, Duvigneaud \& Denaeyer-De Smet 1963). The Katangan metallicolous flora, known as the copper flora, hosts about 600 plant species tolerant to high concentrations of $\mathrm{Cu}-\mathrm{Co}$ in soils (metallophytes) (http://copperflora.org/), 32 of which are strict endemics of metal-rich soil and 24 are broad endemics (Faucon et al. 2010). Katangan metallophytes represent an important biological resource to the D.R.Congo, as they might serve in the ecological restoration of heavy metal-polluted soils (Whiting et al. 2002, 2004, Faucon et al. 2010). Due to the revival of mining activities, most Katangan copper outcrops have been allotted to mining companies (Malaisse et al. 1999, Whiting et al. 2004) and will be irreversibly damaged in the coming decades. A number of endemics have already become extinct (Faucon et al. 2010, Faucon et al. 2012b).

Pioneering studies on these ecosystems, based on a classical phytosociological approach (Duvigneaud 1958, Duvigneaud \& Denaeyer-De Smet 1963, Malaisse et al. 1994), revealed the existence of patterns of vegetation on copper hills, with characteristic zonation along the slopes. Plant communities for each outcrop were organised along steep $\mathrm{Cu}$ gradients related to the outcrop topography (Duvigneaud \& Denaeyer-De Smet 1963). However, plant communities described by physiognomic criteria did not provide a fine scale understanding of plant community diversity in relation to edaphic factors. Recent studies, based on modern sampling methods, support the idea that other soil factors, especially $\mathrm{pH}, \mathrm{Mn}$-oxides, Fe-oxides and organic matter should also be considered (Kabala \& Singh 2001, Neaman et al. 2009, Faucon et al. 2011a). Interaction with metals other than $\mathrm{Cu}$ and Co might also limit their bioavailability and thus soil toxicity. Saad et al. (2012) suggested that nutrient status might also be of prime importance. To date, no detailed studies have focused on an assessment of the diversity of $\mathrm{Cu}$ plant communities in relation to edaphic factors at a small scale. Patchiness of metalliferous habitat might lead to high beta (inter-site) diversity for flora (Harrison \& Inouye 2002, Harrison \& Rajakaruna 2011), thus obscuring intra-site variation in large-scale studies. Examining the small-scale diversity of plant communities within single $\mathrm{Cu}$ sites is particularly important, to assess the effort that should be devoted to restoration strategies.

Apart from plant assemblages, single species belonging to similar plant communities are expected to react differently to the combination of environmental groupings. Understanding the individual niche of metallophyte species as well as the niche distribution along environmental gradients is essential for a fine-tuning of species conservation strategies in restored habitats (Bizoux et al. 2004, Chipeng et al. 2010, Faucon et al. 2011b). The ecological niches of only a few species growing on $\mathrm{Cu}$ outcrops have been characterised: Ocimum centrali-africanum (Howard-Williams 1970), Haumaniastrum katangense (Malaisse \& Brooks 1982, Paton \& Brooks 1996, Chipeng et al. 2010), Mimulus cupriphilus, M. guttatus (Macnair \& Gardner 1998), Crepidorhopalon perennis and C. tenuis (Faucon et al. 2012b).

In this study, we address the degree to which small-scale continuous edaphic gradients can contribute to plant assemblage diversity and the consequences for restoration of metallophyte vegetation. The specific objectives of this study were to: (1) analyse the pattern of fine-scale plant community variation within a $\mathrm{Cu}$ site subject to a strong ecological gradient; (2) assess the distribution of ecological niches for a set of species representative of those communities for conservation and restoration purposes, and (3) compare our results with those of other studies performed on a larger scale, to infer implications for plant communities and species conservation at the small scale.

\section{MATERIALS AND METHODS}

\section{Site description}

Kinsevere outcrop is located at $11^{\circ} 36^{\prime} \mathrm{S} 27^{\circ} 58^{\prime} \mathrm{E}$ in the eastern part of the Katangan Copper Belt, 30 km north-north-east of Lubumbashi, D.R.Congo. The outcrop (surface approximately 9 ha, hill height around $25 \mathrm{~m}$ ) is covered by swards on a plateau $(1,263 \mathrm{~m})$ with a gentle slope and flat area (contamination dembo) at the base of the outcrop, both character- 
ized by steppic savannas. The copper hill is surrounded by miombo woodland with Brachystegia spp. Swards occur on reworked mine debris and consist of open vegetation mainly composed of annual species, long-lived short grasses and dicotyledonous species not exceeding $40 \mathrm{~cm}$ in height. Steppe savannas consist of dense vegetation on primary habitats dominated by long-lived tall grasses and dicotyledons with woody underground systems not exceeding $80 \mathrm{~cm}$ in height.

The climate is subtropical humid, CW6s according to the Köppen classification (Bultot 1950). There is one rainy season (November to March) and one dry season (May to September), with two transition months (October and April). Mean total annual rainfall is $1.273 \mathrm{~mm}$ of which $1.122 \mathrm{~mm}$ falls during the rainy season (Anvil Mining Compagny Katanga, unpubl. data). Mean annual temperature is $21^{\circ} \mathrm{C}$. The temperature is the lowest at the beginning of the dry season $\left(15-17^{\circ} \mathrm{C}\right)$. September and October are usually the warmest months with daily maxima of $31-33^{\circ} \mathrm{C}$. The rainy season is characterised by the flowering of grasses and the dry season, by flowering of geophyte species stimulated by wildfires.

\section{Soil sampling and vegetation cover estimation}

Vegetation was sampled along two parallel transects $(230 \mathrm{~m}$ in length) placed north-east to south-west along the main slopes. The transects were $25 \mathrm{~m}$ apart and encompassed the entire physiognomic variation of the outcrop's vegetation related to the topographic gradient. Forty eight permanent $1 \mathrm{~m}^{2}$ plots were located at $10 \mathrm{~m}$ interval along the transects.

To characterise plant communities, all plant species were recorded in each plot on four dates, corresponding to the phenological variation of Katangan vegetation: August 2008 (end of dry season), December 2008 (first part of wet season), February 2009 (mid wet season) and April 2009 (beginning of dry season). Species abundances were recorded using the Braun-Blanquet scale: $+:<1 \%$ cover, $1: 2-5 \%$ cover, 2: $6-25 \%$ cover, $3: 26-50 \%$ cover, $4: 51-75 \%$ cover and 5 : $76-100 \%$ cover (Poore 1955). Nomenclature was based on the Flora Zambesiaca (Board of Trustees Kew Royal Botanic Gardens 1960-2010) and the Flore d'Afrique Centrale (Bamps 1973-1993). Authors of taxa and families to which they belong are given in the electronic appendix 1 .

Plant collections were deposited at the herbaria of the Faculty of Agronomy (University of Lubumbashi) and the Biodiversity and Landscape Unit (Gembloux, Belgium). Composite soil samples $(200 \mathrm{~g})$ were collected in December 2008 in the upper soil layer $(0-40 \mathrm{~cm})$ of each plot. Each sample consisted of a bulk of five samples collected in the centre and the four corners of the $1 \mathrm{~m}^{2}$ plot. Soil samples were air-dried and sieved to $2 \mathrm{~mm}$ and the percentage of stones $(>2 \mathrm{~mm})$ was measured. The $\mathrm{pH}$ was measured in water or in $1 \mathrm{~N} \mathrm{KCl}$ with a glass electrode in a $2: 5$ soil:solution ratio and with $2 \mathrm{~h}$ equilibration time. Total organic content was measured following the Springer-Klee method (Springer \& Klee 1954), via hot oxidation with $\mathrm{K}_{2} \mathrm{Cr}_{2} \mathrm{O}_{7}$ and titration of the excess oxidant with $\left(\mathrm{NH}_{4}\right)_{2} \mathrm{Fe}\left(\mathrm{SO}_{4}\right)_{2} 6 \mathrm{H}_{2} \mathrm{O}$. Total nitrogen was determined following the Kjeldahl method (Bremner $\&$ Mulvaney 1982). The bioavailability of $\mathrm{Cu}, \mathrm{Co}, \mathrm{Zn}, \mathrm{Fe}$, $\mathrm{Mn}, \mathrm{K}, \mathrm{Mg}, \mathrm{Ca}$ and $\mathrm{P}$ were determined after an extraction by $1 \mathrm{~N} \mathrm{CH}_{3}$ COONH4EDTA (pH 4.65) for $30 \mathrm{~min}$ (ratio soil:solution of 1:5) (Lakanen \& Erviö 1971). The supernatant was filtered through a S\&S 595 folded filter and analysed using a flame atomic absorption spectrometer (Varian 220). Phosphorus content was determined with a Shimadzu UV1205 spectrophotometer (Shimadzu Corporation) at $430 \mathrm{~nm}$ after the development of blue colouration.

\section{Identification of plant communities}

Prior to statistical analysis, Braun-Blanquet coefficients were transformed into ordinal van der Maarel values: 1, 3, 5, 7, 8 and 9 (van der Maarel 2005). All seasonal relevés were compiled, selecting the highest abundance of each species in a plot. This method allows the phenological variation of flora in Katanga to be taken into account (Saad et al. 2012). Plant communities were identified through a hierarchical UPGMA classification using the Bray-Curtis distance (Dufrêne \& Legendre 1997). The resulting hierarchical tree was analysed to define the main plant communities at $80 \%$ similarity. The $80 \%$ similarity criterion was selected, to allow comparison of results to those of recent studies (Saad et al. 2012). Indicator species for each plant community were identified with the IndVal method (Dufrêne \& Legendre 1997). To examine the relationships between floristic data and the different edaphic variables, a Canonical Correspondence Analysis (CCA) was performed. Finally, one-way Kruskal-Wallis non-parametric ANOVA followed by Tukey's HSD test was performed to test differences between environmental variables among plant communities identified with the hierarchical classification (Oksanen 2010). Because edaphic parameters might covary along environmental gradients, we first explored the structure of edaphic factor variation at the study site via Principal Component Analysis (PCA).

\section{Species ecological amplitude}

The distribution of ecological niches along edaphic factors was explored for twelve species present in at least ten plots: Andropogon schirensis, Bulbostylis pseudoperennis, Cryptosepalum maraviense, Digitaria nitens, Eragrostis racemosa, Gladiolus tshombeanus, Hibiscus rhodanthus, Loudetia simplex, Monocymbium ceresiiforme, Ocimum centrali-africanum, Scleria sp. and Tristachya bequaertii. Generalised additive models (GAM; Hastie \& Tibshirani 1990) - a nonparametric extension of generalised linear models (GLM) with binomial likelihoods were used to model the probability of species abundance in relation to edaphic parameter values (Lepš \& Šmilauer 1999) using CANOCO version 4.5 (ter Braak \& Šmilauer 2002).

In a first step, each edaphic parameter $\mathrm{pH}$ water, $\mathrm{pH} \mathrm{KCl}$, $\mathrm{Cu}, \mathrm{Co}, \mathrm{C}, \mathrm{N}, \mathrm{P}, \mathrm{Cd}, \mathrm{Zn}, \mathrm{Fe}, \mathrm{Mg}, \mathrm{K}, \mathrm{Pb}, \mathrm{Mn}, \mathrm{Ca}, \%$ rock cover, \% stones in soil, slope) was separately tested against the twelve species. Only edaphic parameters for which at least half of the species had a significant GAM model ( $\mathrm{P}<$ 0.01 ) were retained. To select the main factors potentially affecting species ecological niches at the studied site, we retained edaphic factors that best explained the abundance of the twelve selected species in a Canonical Correspondence Analysis (CCA). For each of the retained combinations, species-edaphic parameters, and the optimum and central border of the niche amplitude were estimated. The central 
border is equivalent to the classical estimation of tolerance for the Gaussian response curve (Heegaard 2002, Heikkinen \& Mäkipää 2010).

The fraction defining the central borders was computed following the formula: $\mathrm{c} \times \exp \left({ }^{-2}\right)$; with (c) as the maximum response (Heegaard 2002).

\section{RESULTS}

\section{Edaphic factor variation}

Variation among plant communities is the result of geochemical contamination primarily by $\mathrm{Cu}$, possibly associated with $\mathrm{Ca}, \mathrm{Zn}, \mathrm{Pb}, \mathrm{Cd}$ and to a lesser degree, the effect of organic matter. The first two axes of the PCA for eighteen edaphic variables explained $50 \%$ of the total variation (fig. 1). The variables that best correlated with PCA1 were $\mathrm{Cu}, \mathrm{pH} \mathrm{KCl}$, $\mathrm{N}, \mathrm{C}, \mathrm{Zn}, \mathrm{Cd}, \mathrm{Ca}, \mathrm{Pb}$ and $\mathrm{P}$ (positive correlation) and the variables best correlated with PCA2 were \% rock cover, $\%$ stones in soil and $\mathrm{Co}$ (positive correlation) and $\mathrm{K}, \mathrm{Fe}$ and $\mathrm{Mg}$ (negative correlation). On the second axis, without relation to the first axis, a greater \% rock cover on the surface was associated with a greater \% stones in soil and the poorest correlation was the habitat i.e. deficiencies in $\mathrm{Mg}$, Fe and $\mathrm{K}$ (fig. 1). Altogether, the analysis suggests intercorrelation among numerous edaphic variables. Four main groups of parameters were identified: $\mathrm{Cu}-\mathrm{pH} \mathrm{KCl}-\mathrm{P}, \mathrm{N}-\mathrm{C}-\mathrm{Zn}-\mathrm{Cd}, \%$ rock cover-\% stones in soil-Co, this latest opposed to Mg-Fe-K.

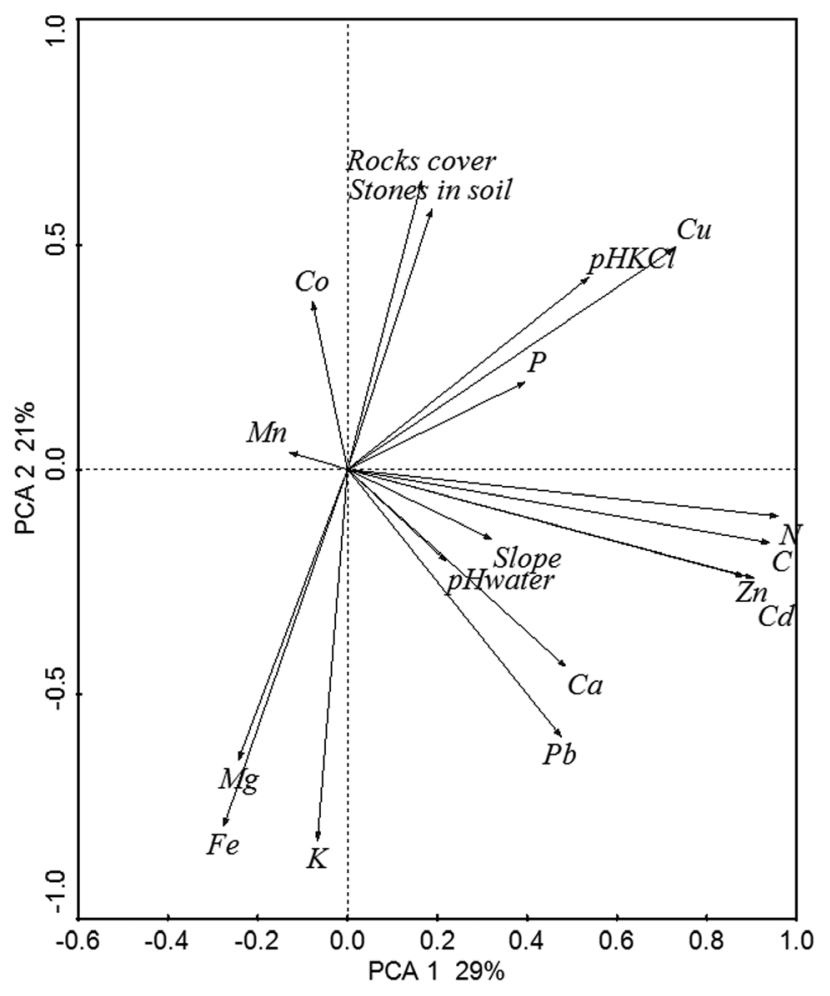

Figure 1 - Principal Component Analysis of 18 edaphic factors in $48,1 \mathrm{~m}^{2}$ plots on the Kinsevere copper outcrop. Arrows represent edaphic factors.

\section{Plant communities}

A total of 64 species were identified in the 48 plots. Five groups of plots were identified from the hierarchical classification at $80 \%$ similarity, and were interpreted as five different plant communities (fig. 2A \& B). Each community was well characterized by a set of indicator species (fig. 2A \& B).

Communities I and III corresponded to swards and steppe savanna, respectively, supplied with malachite gravel from the outcrop plateau. An indicator species for community I was Haumaniastrum katangense, an annual species. Community II corresponded to sward developing mainly on the plateau with a high proportion of malachite. Indicator species for community II were three short-stature perennial species with low rooting-depth systems: Lapeirousia erythrantha, Ipomoea linosepala subsp. linosepala and Bulbostylis pseudoperennis. Community III was characterised by Commelina sp., Bulbostylis filamentosa a short hemicryptophyte, and Vernonia suprafastigiata, a species developing a deep underground xylopode. Communities IV and V were typical steppe savannas located on different parts of the topographical gradient: the outcrop foot for community IV and dembo for community V. Community IV was characterised by Tristachya bequaertii and Digitaria nitens, two clonal gramineae, and Cryptosepalum maraviense, a soil-covering sub-shrub with well-developed underground xylopodes. Community V was also dominated by gramineous species; its indicator species were three sub-shrubs with well-developed underground xylopodes: Eriosema englerianum, Hibiscus rhodanthus and Ocimum centrali-africanum (fig. 2A \& B).

\section{Plant communities and edaphic factors}

Five groups of relevés identified in the clustering analysis were distinguished well in the CCA analysis. The first two axes of the CCA explained $37 \%$ of the total variation. The first axis clearly opposed Communities I, II and III (positive values) to communities IV and V (negative values) and was positively correlated with trace metals and $\mathrm{C}-\mathrm{N}$ content and negatively correlated with $\mathrm{Mg}, \mathrm{K}$ and $\mathrm{Fe}$.

Community II was also distinct from community I and III along axis 1 but the two latter communities were less distinguished. Axis 2 clearly separated communities IV and V, with negative coordinates for community IV being correlated mainly with slope, \% of stones in soils and Fe.

There were differences in mean edaphic variables among the three communities for 12 of the 20 variables tested (table 1). Due to the number of tests and the intercorrelation of edaphic variables (table 1), associated probabilities should be taken with caution. However, careful examination of intercommunity differences highlights the complex nature of relationships among plant communities and edaphic parameters.

$\mathrm{Cu}$ was the best discriminating factor among communities $\left(\mathrm{F}_{4.34}=52.74\right)$ and clearly distinguished communities I and III from community II with a high mean $\mathrm{Cu}$ content $(1,131-12,874 \mathrm{mg} / \mathrm{kg})$ and community IV from community $\mathrm{V}$ with a lower mean $\mathrm{Cu}$ soil content (111-289 mg/kg). The soil of community II not only exhibited the highest level of 

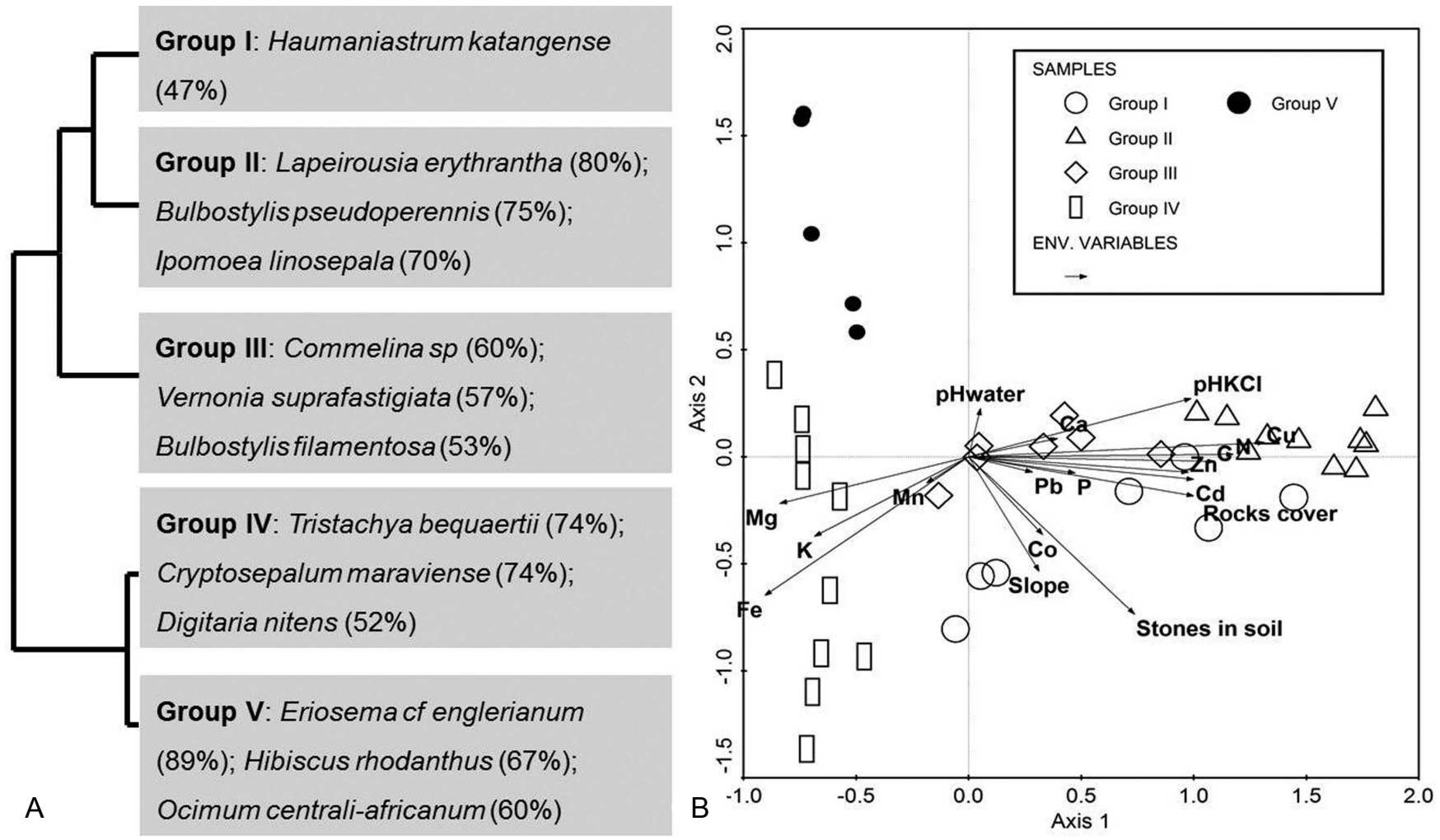

Figure 2 - Identification of plant communities, indicator species and relationships with edaphic parameters on the Kinsevere copper outcrop, Katanga, D.R.Congo. A, dendrogram generated from an UPGMA analysis performed on the Bray-Curtis distance similarity of species composition in $1 \mathrm{~m}^{2}$ plots. Indicator species are shown with their IndVal value in brackets. B, canonical correspondence analysis (CCA) based on species composition and 18 environmental parameters in $48,1 \mathrm{~m}^{2}$ plots. The first two axes of the CCA explained $37 \%$ of the total variation.

Table 1 - Mean and standard errors of edaphic factors for the partitions in five communities identified at the Kinsevere copper outcrop.

*Significant differences in mean edaphic factors among groups after Bonferonni adjustment: $P<0.003$. (Bonferonni adjustment: $P$ value $=$ $0.05 / \mathrm{n}$ variables); Superscript letters (a,b,c,d) indicate homogeneous groups (Tukey's HSD test, Kruskal Wallis non parametric ANOVA); $\mathrm{n}=$ number of samples per group. $F_{4,34}=$ Fischer significance test at 4 and 34 degree of freedom.

\begin{tabular}{|c|c|c|c|c|c|c|}
\hline \multirow{2}{*}{ Environment variables } & \multicolumn{5}{|c|}{ Group } & \multirow[b]{2}{*}{$F_{4,34}$} \\
\hline & $1(\mathrm{n}=7)$ & $2(n=10)$ & $3(n=7)$ & $4(n=10)$ & $5(\mathrm{n}=5)$ & \\
\hline pHwater & $5.2(0.4)^{\mathrm{a}}$ & $5.5(0.3)^{\mathrm{a}}$ & $5.4(0.2)^{\mathrm{a}}$ & $5.5(0.2)^{\mathrm{a}}$ & $5.4(0.2)^{\mathrm{a}}$ & 0.54 \\
\hline $\mathrm{pHKCl}$ & $4.4(0.3)^{a}$ & $4.8(0.2)^{\mathrm{b}}$ & $4.3(0.2)^{\mathrm{a}}$ & $4.3(0.3)^{\mathrm{a}}$ & $4.2(0.1)^{\mathrm{a}}$ & $6.77^{*}$ \\
\hline $\mathrm{C}(\mathrm{g} / 100)$ & $1.7(0.7)^{\mathrm{a}}$ & $6.1(1.5)^{\mathrm{c}}$ & $4.3(1.6)^{\mathrm{b}}$ & $2.9(0.5)^{\mathrm{b}}$ & $2.1(0.3)^{\mathrm{a}}$ & $35.89 *$ \\
\hline$N(g / 100)$ & $0.13(0.05)^{\mathrm{a}}$ & $0.44(0.09)^{\mathrm{c}}$ & $0.3(0.12)^{\mathrm{c}}$ & $0.19(0.02)^{b}$ & $0.15(0.02)^{\mathrm{a}}$ & $29.66^{*}$ \\
\hline $\mathrm{Cu}(\mathrm{mg} / \mathrm{kg})$ & $1131(1149)^{\mathrm{c}}$ & $12874(6099)^{\mathrm{d}}$ & $1854(1780)^{\mathrm{c}}$ & $289(84)^{\mathrm{b}}$ & $111(52)^{\mathrm{a}}$ & $52.74 *$ \\
\hline Co $(\mathrm{mg} / \mathrm{kg})$ & $6.6(6.5)^{\mathrm{a}}$ & $3.2(4.1)^{\mathrm{a}}$ & $3.4(4.3)^{\mathrm{a}}$ & $2.6(2.2)^{\mathrm{a}}$ & $2.5(1.1)^{\mathrm{a}}$ & 0.58 \\
\hline $\mathrm{Zn}(\mathrm{mg} / \mathrm{kg}$ & $0.97(0.7)^{\mathrm{a}}$ & $4.89(2.77)^{\mathrm{b}}$ & $2.34(1.93)^{\mathrm{a}, \mathrm{b}}$ & $1.58(0.79)^{\mathrm{a}}$ & $0.96(0.23)^{\mathrm{a}}$ & $9.14 *$ \\
\hline $\mathrm{Cd}(\mathrm{mg} / \mathrm{kg})$ & $0.03(0.03)^{\mathrm{a}}$ & $0.18(0.09)^{\mathrm{c}}$ & $0.11(0.07)^{b, c}$ & $0.07(0.02)^{b}$ & $0.03(0.02)^{\mathrm{a}}$ & $15.22 *$ \\
\hline $\mathrm{Pb}(\mathrm{mg} / \mathrm{kg})$ & $1.64(0.89)^{\mathrm{a}}$ & $2.77(2.4)^{\mathrm{a}}$ & $3.37(2.54)^{\mathrm{a}}$ & $2.29(0.79)^{\mathrm{a}}$ & $2.26(0.23)^{\mathrm{a}}$ & 0.76 \\
\hline $\mathrm{Ca}(\mathrm{mg} / \mathrm{kg})$ & $77(72)^{\mathrm{a}}$ & $176(149)^{\mathrm{a}}$ & $151(108)^{\mathrm{a}}$ & $124(99)^{\mathrm{a}}$ & $87(63)^{\mathrm{a}}$ & 1.35 \\
\hline $\mathrm{Mg}(\mathrm{mg} / \mathrm{kg})$ & $79(31)^{a, b}$ & $57(32)^{a}$ & $138(48)^{b, c}$ & $196(89)^{c}$ & $81(36)^{a, b}$ & $12.93 *$ \\
\hline $\mathrm{K}(\mathrm{mg} / \mathrm{kg})$ & $76(44)^{a, b}$ & $67(46)^{\mathrm{a}}$ & $110(57)^{\mathrm{a}, \mathrm{b}}$ & $143(48)^{\mathrm{b}}$ & $101(66)^{\mathrm{a}, \mathrm{b}}$ & 4.2 \\
\hline $\mathrm{Mn}(\mathrm{mg} / \mathrm{kg})$ & $49(44)^{\mathrm{a}}$ & $31(39)^{\mathrm{a}}$ & $48(31)^{\mathrm{a}}$ & $54(32)^{\mathrm{a}}$ & $24(10)^{\mathrm{a}}$ & 2.01 \\
\hline $\mathrm{Fe}(\mathrm{mg} / \mathrm{kg})$ & $65(32)^{a}$ & $43(21)^{\mathrm{a}}$ & $115(32)^{b}$ & $135(34)^{b}$ & $60(9)^{\mathrm{a}}$ & $15.73 *$ \\
\hline $\mathrm{P}(\mathrm{mg} / \mathrm{kg})$ & $143(237)^{\mathrm{a}}$ & $213(86)^{\mathrm{b}}$ & $67(43)^{\mathrm{a}}$ & $83(136)^{\mathrm{a}}$ & $27(5)^{\mathrm{a}}$ & $8.44^{*}$ \\
\hline Slope $\left({ }^{\circ}\right)$ & $11(12)^{a, b}$ & $13(7)^{b}$ & $13(9)^{\mathrm{b}}$ & $12(5)^{\mathrm{b}}$ & $0(0)^{\mathrm{a}}$ & $4.34 *$ \\
\hline Stones in soil (\%) & $52(6)^{c}$ & $42(11)^{b, c}$ & $30(10)^{a, b}$ & $29(10)^{\mathrm{b}}$ & $17(6)^{\mathrm{a}}$ & $14.01 *$ \\
\hline Rocks cover $(\%)$ & $77(37)^{\mathrm{c}}$ & $51(32)^{b, c}$ & $13(16)^{a, b}$ & $8(7)^{\mathrm{a}}$ & $0(0)^{\mathrm{a}}$ & $10.7^{*}$ \\
\hline
\end{tabular}


$\mathrm{Cu}$ but was also distinguished from other communities by higher levels of $\mathrm{C}$ and P. The soil of community I, while exhibiting very similar levels of $\mathrm{Cu}$ to community III, was distinguished by lower levels of $\mathrm{C}$ and $\mathrm{N}$.

Communities III and IV, while very different in $\mathrm{Cu}$ content, were both distinguishable from other communities by higher levels of $\mathrm{Fe}$ and, in part, $\mathrm{Mg}$. The physical structure of the soil was also different among communities with soils of community IV and V, exhibiting a lower \% stones in soil and lower \% rock cover as compared to community I. Communities II and III showed intermediate mean values for these parameters.

\section{Species ecological niches}

For thirteen out of the eighteen edaphic variables, at least six species displayed a significant GAM model: \% rock cover $(\mathrm{n}=12) ; \mathrm{Cu}(\mathrm{n}=10) ; \mathrm{pH} \mathrm{KCl}(\mathrm{n}=10) ; \mathrm{C}(\mathrm{n}=9) ; \mathrm{N}(\mathrm{n}=9)$; $\mathrm{P}(\mathrm{n}=9) ; \mathrm{Cd}(\mathrm{n}=9) ; \mathrm{Zn}(\mathrm{n}=8) ; \mathrm{Fe}(\mathrm{n}=7) ; \mathrm{Mg}(\mathrm{n}=7) ; \mathrm{K}$ $(\mathrm{n}=7) ; \mathrm{Pb}(\mathrm{n}=7) ; \%$ stones in soil $(\mathrm{n}=6)$.

From these edaphic parameters, \% rock cover, $\mathrm{Cu}, \mathrm{pH}$ $\mathrm{KCl}$ and \% stones in soil were the most prominent in ex- plaining the variation in abundance of the twelve species in relation to edaphic factors based on a CCA analysis for these twelve species (not shown). Repartition of the niche optimum along the environmental gradients was different among the chemical and physical soil parameters (fig. 3). For $\mathrm{Cu}$, ten species were situated with no niche optimum within the intermediate value, irrespective of the value of the gradient. The superimposition of ecological niches for $\mathrm{Cu}$ content was due to differences in niche amplitude among species with the highest optimum, also exhibiting the largest niche. A similar bimodal pattern was found for $\mathrm{pH} \mathrm{KCl}$. In contrast, niche optima were distributed normally along the gradient for physical parameters (\% rock cover and \% stones in soil), but a tendency to increase in niche amplitude with an increase in optimum values was also observed.

\section{DISCUSSION}

Pattern of fine scale plant community variation within a $\mathrm{Cu}$ site subjected to a strong ecological gradient

A small-scale gradient of environmental conditions is important to evolutionary processes, species coexistence and

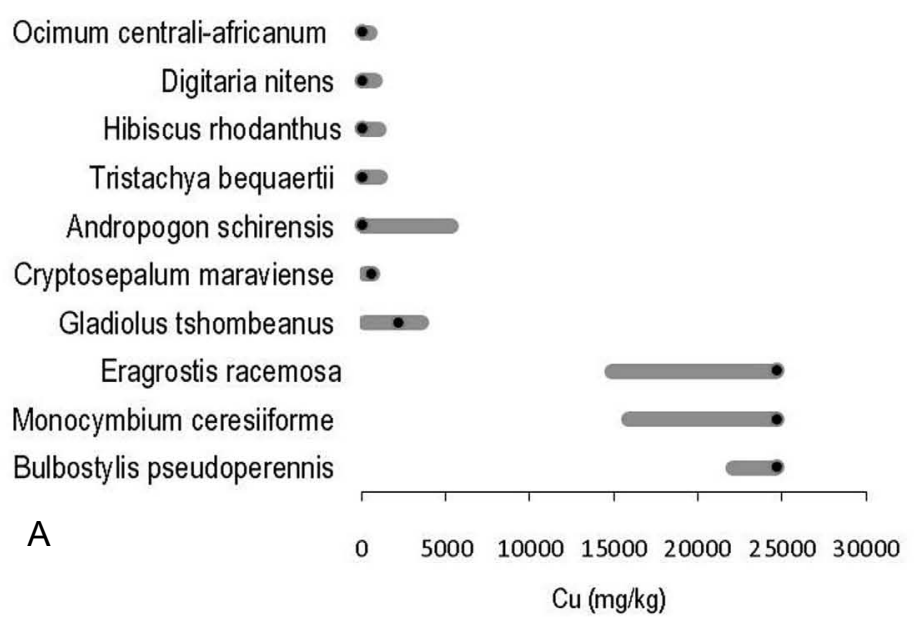

Ocimum centrali-africanum Cryptosepalum maraviense Loudetia simplex Digitaria nitens Andropogon schirensis Hibiscus rhodanthus Gladiolus tshombeanus Tristachya bequaertii Scleria sp. Monocymbium ceresiiforme Eragrostis racemosa Bulbostylis pseudoperennis

\section{B}

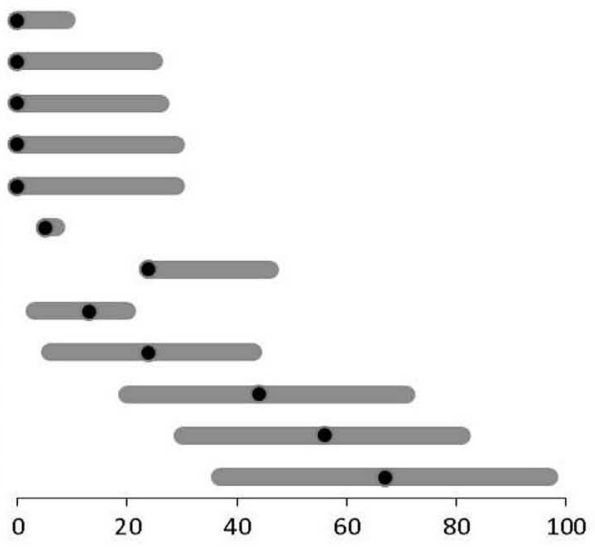

Rocks cover (\%)
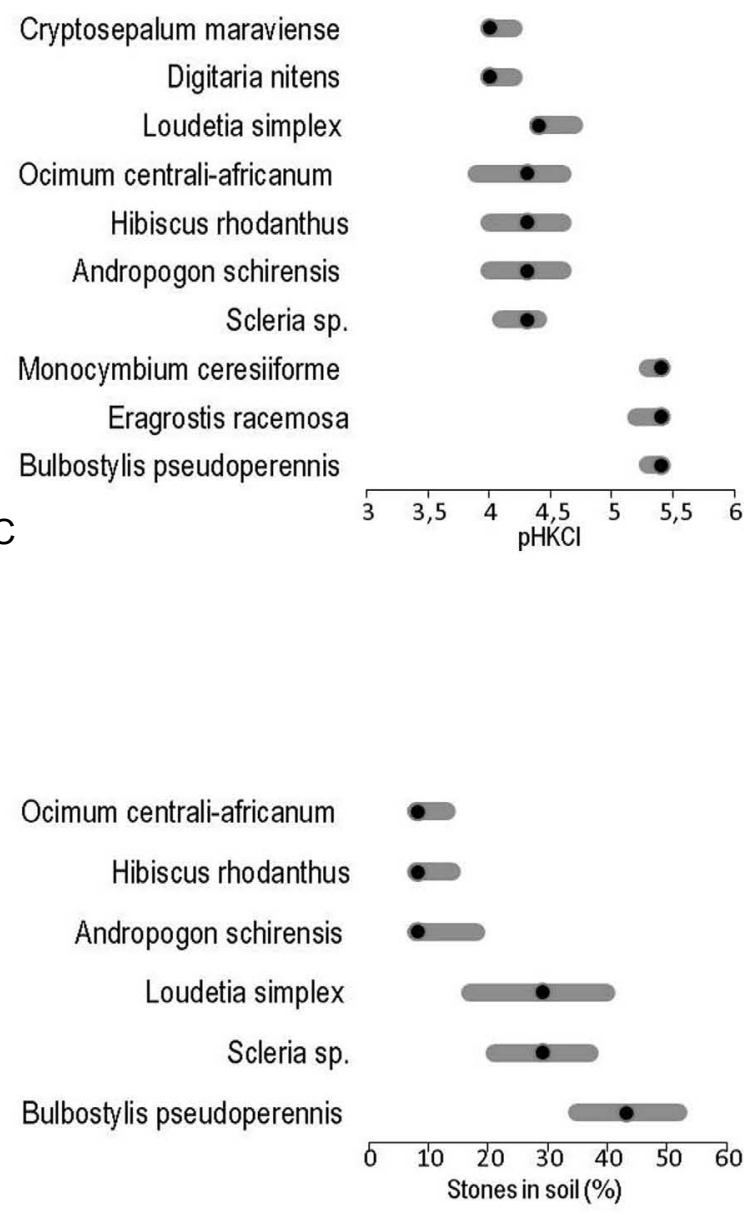

D

Figure 3 - Estimation of species ecological responses along environmental gradients with the optimum (black dot) and central borders (grey line). A, $\mathrm{Cu} ; \mathrm{B}, \%$ rock cover; $\mathrm{C}, \mathrm{pH} \mathrm{KCl} ; \mathrm{D}, \%$ stones in soil. 
ultimately to the diversity of plant assemblages (Silvertown 2004). In this study, we found complex variation of edaphic conditions within a single metalliferous site. Such a complex pattern of edaphic variation is generated by a high covariation among edaphic factors. Small-scale edaphic variation within a single $\mathrm{Cu}$ site appeared as large as the variation demonstrated for combinations of $\mathrm{Cu}$ sites over a large spatial scale in both physical (stones in soil, rock cover) and chemical factors $(\mathrm{Cu}, \mathrm{Fe}, \mathrm{Mg}, \mathrm{P}, \mathrm{K}, \mathrm{N}, \mathrm{C}$, and $\mathrm{Zn}$ ) (Faucon et al. 2011b, 2012b, Saad et al. 2012). This variation in edaphic factors generates a highly heterogeneous environment, promoting niche diversity and therefore inducing a high diversity of plant assemblage over limited areas. The diversity of plant communities $(\mathrm{N}=5)$ identified in our study site was higher than that $(\mathrm{N}=3)$ identified by Saad et al. (2012) over six isolated $\mathrm{Cu}$ outcrops at a sub-regional scale based on the same criteria of analyzing plant-edaphic relationships.

This high local diversity of plant communities might be interpreted with respect to different combinations of edaphic conditions, in agreement with most recent studies on $\mathrm{Cu}$ vegetation (Faucon et al. 2011b, Saad et al. 2012). Obviously, due to its large variation, $\mathrm{Cu}$ concentration is the most discriminant edaphic factor among identified plant communities. However, not only variation in the concentration of $\mathrm{Cu}$ might be determinant for the structuration of plant diversity on $\mathrm{Cu}$ outcrops: analysis of covariation among floristic data and edaphic data (CCA) indicated a correlation of numerous edaphic factors with floristic variation.

Detailed comparisons of mean edaphic factors among communities also revealed individual combinations of edaphic parameters for each community apart from differences in soil $\mathrm{Cu}$ content. Nevertheless, correlations among edaphic factors should be taken with caution, given differences in soil properties due to horizon depth differences between habitats. Communities with a high level of soil $\mathrm{Cu}$ (I, II, III) also differed in other parameters including nutrients. Metallicolous communities associated with higher nutrient concentrations than other communities, differ from those on serpentine soils, where deficiency of N, P, K and Ca has been suggested as a potential reason for limited plant productivity (Kruckeberg 1984, O'Dell et al. 2006). Communities with a lower $\mathrm{Cu}$ contamination (IV, V) also differed from each other notably in $\mathrm{Fe}$ and $\mathrm{Mg}$. Heavy metals are antagonistic to the uptake of other elements (Kazakou et al. 2008) and high values of $\mathrm{Fe}$-oxides can limit $\mathrm{Cu}$ availability and thus its toxicity at low contamination levels (Kabala \& Singh 2001). Furthermore, $\mathrm{Fe}$ is known to have antagonist effects on $\mathrm{Cu}$ uptake (Faucon et al. 2009). The large variation in physical properties of soil observed in our study should also play a role in filtering the assemblage of plants on $\mathrm{Cu}$-rich soil. This might promote specific local conditions, such as reworked substrate typical of community I, where the therophytic pioneer species Haumaniastrum katangense dominates (Faucon et al. 2011b). Interestingly, Saad et al. (2012) found similar patterns of covariation in a multi-site study situated in another Katangan region (Tenke), with strong correlations within the same groups of edaphic factors: $\mathrm{N}-\mathrm{C}$ and Fe-Mg-K. Covariation was shown by $\mathrm{C}$ and $\mathrm{N}$, which is possibly explained by a high $\mathrm{Cu}$ content reducing mineralisation speed. The negative correlation between \% stones in soil-rock cover and Mg-
Fe-K might be explained by dilution of fine soil particles by quartz or by the presence of clayey rocks on the slope. High covariation appears to be an essential trait of edaphic factor variation of Katangan $\mathrm{Cu}$-rich soils. This will make it difficult to examine separately the effect of these factors on plant community structures.

The plant communities identified in our study based on modern quantitative methods match closely the vegetation units identified via physiognomic criteria or traditional phytosociological approaches in pioneer studies (Duvigneaud 1958, Duvigneaud \& Denaeyer-De Smet 1963). The first partition of the hierarchical clustering establishes the wellknown distinction between low mineralized steppic savannas and highly contaminated swards. Individual communities might also be linked to previously described vegetation units: community I and III = swards with annual polycuprophytes on disturbed soil; community II = sward/steppe with polycuprophytes; community IV = steppic savanna on slope; community $\mathrm{V}=$ dembo steppic savanna.

\section{Distribution of ecological species niches in heterogeneous environment}

The concept of the ecological niche holds a central role in ecology as it has been widely used to understand species coexistence within communities and to predict species distribution along environmental gradients (Violle \& Jiang 2009).

Wide variation in edaphic factors might also be expected to promote a diversity of ecological niches for individual species. Niche distribution along edaphic gradients has not been previously examined for species growing on $\mathrm{Cu}$ outcrops. Our results showed two different patterns for soil chemical and physical parameters. Niche optimum distribution was clearly bimodal for chemical factors, particularly for $\mathrm{Cu}$. However, a high proportion of species with a niche optimum at the lowest $\mathrm{Cu}$ concentrations might partly be due to the fact that $67 \%$ of quadrats contained fewer than $1,000 \mathrm{ppm}$ of soil $\mathrm{Cu}$. In contrast, the distribution of the niche optimum was more regular along the gradient of physical parameters. Examination of niche amplitude also generates interesting hypotheses concerning the evolution of tolerance along edaphic gradients (Baack et al. 2006). For $\mathrm{Cu}$, species with a niche optimum at higher concentrations displayed larger amplitudes and probably greater tolerance, than species with a niche optimum at lower concentrations. A similar pattern was observed for physical parameters (rock cover and stones in soil). These patterns should be interpreted with caution, due to the low number of species examined, but might suggest new hypotheses to be further tested in a larger context.

Fine-scaled ecological heterogeneity conditions probably play important roles in niche distribution. Some situations might cause divergent selection in the population and thus contribute to ecotypic differentiation (Antonovics et al. 1987, Bischoff et al. 2006).

In this study, the Ocimum centrali-africanum niche optimum, was limited only to soils with a lower $\mathrm{Cu}$ concentration compared to that in Howard-Williams (1970, 1971), where it was reported to vary in different soil types. This might be partly explained by constrained physical factors associated with the metal-rich soil of Katanga, namely $\%$ rock cover. 


\section{Ecological restoration, a challenge due to significant small-scale variation of plant assemblages}

Our study demonstrated a high degree of small-scale diversity in plant communities $(\mathrm{n}=5)$ along a $\mathrm{Cu}$ gradient in combination with several other edaphic factors. This is complementary to the lower diversity of plant communities found by Saad et al. (2012) at a regional scale. Hence, our results suggest the importance of further examination of $\mathrm{Cu}$ plant community diversity in a hierarchical spatial framework, if relevant conservation programmes have to be designed. Our results also indicate that maintaining the diversity of plant assemblages in post-mining rehabilitation programmes might be challenging, due to significant small-scale variation within those plant assemblages. With regard to restoration, actions to be promoted to limit the impact of mining activities on those ecosystems should pay special attention to the recreation of heterogeneous and specific conditions similar to those of plant communities (Pope et al. 2010, Lazarus et al. 2011). However, full restoration after re-establishing historic soil conditions will be achieved by avoiding changes in soil conditions, such as nutrient pollution, which alleviate edaphic stress (O’Dell \& Classen 2011).

The largest amplitude of niches with an optimum in the most severe conditions (high $\mathrm{Cu}$ content; rocky substrates), suggests the possibility for those species to be maintained in alternative habitats, for example, in secondary habitats created by mining activities, given the intensity of natural habitat destruction. Such a situation was described by Faucon et al. (2011b) for a $\mathrm{Cu}$ metallophyte but needs to be tested further for other metallophytes in natural habitats and species with a phytoremediation potential.

\section{SUPPLEMENTARY DATA}

Supplementary data are available in pf format at Plant Ecology and Evolution, Supplementary Data Site (http://www. ingentaconnect.com/content/botbel/plecevo/supp-data), and consists of a list of plant species sampled at the Kinsevere copper hill (Katanga, D.R.Congo)

\section{ACKNOWLEDGEMENTS}

The Coopération universitaire au Développement (CUD) is acknowledged for the financial support of this study (PIC REMEDLU). This work is part of the research project 2.4.582.09F funded by the FRS-FNRS ERASMUS programme B. LIEGE 01 and F. BEAUVAIS 02 . We are grateful to MMG Kinsevere (formerly AMCK Kinsevere Mine project) for logistic support during field investigations, particularly to Johnnie Ntukula and Hugues Munung for their assistance.

\section{REFERENCES}

Anvil Mining Compagny Katanga (unpubl. res.) Kinsevere copper mine environment report. Lubumbashi, Anvil Mining.

Antonovics J., Bradshaw A.D., Turner R.G. (1971) Heavy metal tolerance in plants. Advances in Ecological Research 7: 1-85. http://dx.doi.org/10.1016/S0065-2504(08)60202-0
Antonovics J., Clay K., Schmitt J. (1987) The measurement of small-scale environmental heterogeneity using clonal transplants of Anthoxanthum odoratum and Danthonia spicata. Oecologia 71: 601-607. http://dx.doi.org/10.1007/BF00379305

Baack E.J., Emery N.C., Stanton M.L. (2006) Ecological factors limiting the distribution of Gilia tricolor in a California grassland mosaic. Ecology 87: 2736-2745. http://dx.doi. org/10.1890/0012-9658(2006)87\%5B2736:EFLTDO\%5D2.0. $\mathrm{CO} ; 2$

Bamps P. (1973-1993) Flore d'Afrique centrale (Zaïre-RwandaBurundi). Meise, Jardin botanique national de Belgique.

Bergmeier E., Konstantinou M., Tsiripidis I., Sýkora K.V. (2009) Plant communities on metalliferous soils in northern Greece. Phytocoenologia 39: 411-438. http://dx.doi.org/10.1127/0340269X/2009/0039-0411

Bes C.M., Mench M., Aulen M., Gaste H., Taberly J. (2010) Spatial variation of plant communities and shoot $\mathrm{Cu}$ concentrations of plant species at a timber treatment site. Plant and Soil 330: 267-280. http://dx.doi.org/10.1007/s11104-009-0198-4

Bischoff A., Cremieux L., Smilauerova M., Lawson C.S., Mortimer S.R., Dolezal J. (2006) Detecting local adaptation in widespread grassland species - the importance of scale and local plant community. Journal of Ecology 94: 1130-1142. http:// dx.doi.org/10.1111/j.1365-2745.2006.01174.x

Bizoux J.P., Brevers F., Meerts P., Graitson E., Mahy G. (2004) Ecology and conservation of Belgian populations of Viola calaminaria, a metallophyte with a restricted geographic distribution. Belgian Journal of Botany 137: 91-104.

Bizoux J.P., Daïnou K., Raspe O., Lutts S., Mahy G. (2008) Fitness and genetic variation of Viola calaminaria, an endemic metallophyte: implications of population structure and history. Plant Biology 10: 684-693. http://dx.doi.org/10.1111/j.14388677.2008.00077.x

Board of trustees Kew Royal Botanic Gardens (1960-2010) Flora Zambesiaca. Available from: http://apps.kew.org/efloras/search. do [accessed 13 May 2013]

Bremner J.M., Mulvaney C.S. (1982) Nitrogen-Total. In: Page A.L., Miller R.H. Keeny D.R. (eds) Methods of soil analysis. Part 2. Chemical and microbiological properties: 595-624. Madison, Wisconsisn, American Society of Agronomy and Soil Science Society of America.

Brooks R.R., Grégoire J., Madi L., Malaisse F. (1982) Phytogéochimie des gisements cupro-cobaltifères de l'anticlinal de Kasonta (Shaba-Zaïre). Journal of Tropical Geology 6: 219228.

Bultot F. (1950) Carte des régions climatiques du Congo belge établie d'après les critères de Köppen. Bruxelles, Publications du Bureau climatique.

Cailteux J.L.H., Kampunzu A.B., Lerouge C., Kaputo A.K., Milesi J.P. (2005) Genesis of sediment-hosted stratiform copper-cobalt deposits, central African Copperbelt. Journal of African Earth Sciences 42: 134-158. http://dx.doi.org/10.1016/j.jafrearsci.2005.08.001

Chipeng F., Hermans C., Colinet G., Faucon M.P., Ngongo Luhembwe M., Meerts P., Verbruggen N. (2010) Copper tolerance in the cuprophyte Haumaniastrum katangense (S. Moore) P.A. Duvign. \& Plancke. Plant and Soil 328: 235-245. http://dx.doi. org/10.1007/s11104-009-0105-z

Dufrêne M., Legendre P. (1997) Species assemblages and indicator species: The need for a flexible asymmetrical approach. Ecological Monographs 67: 345-366. http://dx.doi. org/10.2307/2963459 
Duvigneaud P. (1958) La végétation du Katanga et des sols métallifères. Bulletin de la Société Royale de Botanique de Belgique 90: $127-286$.

Duvigneaud P., Denaeyer-De Smet S. (1963) Cuivre et végétation au Katanga. Bulletin de la Société Royale de Botanique de Belgique 96: 92-231.

Ernst W.H.O. (1974) Schwermetal vegetation der Erde. Stuttgart, G. Fischer.

Faucon M.P., Chipeng F., Verbruggen N., Mahy G., Colinet G., Shutcha M., Meerts P. (2012a) Copper tolerance and accumulation in two cuprophytes of South Central Africa: Crepidorhopalon perennis and C. tenuis (Linderniaceae). Environmental and Experimental Botany 84: 11-16. http://dx.doi. org/10.1016/j.envexpbot.2012.04.012

Faucon M.P., Colinet G., Jitaru P., Verbruggen N., Shutcha M., Mahy G., Meerts P., Pourret O. (2011a) Relation between cobalt fractionation and its accumulation in metallophytes from south of Central Africa. In: Goldschmidt Conference Abstracts (ed) Mineralogical Magazine 75: 832 .

Faucon M.P., Colinet G., Mahy G., Luhembwe M.N., Verbruggen N., Meerts P. (2009) Soil influence on $\mathrm{Cu}$ and Co uptake and plant size in the cuprophytes Crepidorhopalon perennis and C. tenuis (Scrophulariaceae) in SC Africa. Plant and Soil 317: 201-212. http://dx.doi.org/10.1007/s11104-008-9801-3

Faucon M.P., Meersseman A., Shutcha M.N., Mahy G., Luhembwe M.N., Malaisse F., Meerts P. (2010) Copper endemism in the Congolese flora: a database of copper affinity and conservational value of cuprophytes. Plant Ecology and Evolution 143: 5-18. http://dx.doi.org/10.5091/plecevo.2010.411

Faucon M.P., Parmentier I., Colinet G., Mahy G., Ngongo Luhembwe M., Meerts P. (2011b) May rare metallophytes benefit from disturbed soils following mining activity? The case of the Crepidorhopalon tenuis in Katanga (DR Congo). Restoration Ecology 19: 333-343. http://dx.doi.org/10.1111/j.1526100X.2009.00585.x

Faucon M.P., Tshilong B.M., Van Rossum F., Meerts P., Decocq G., Mahy G. (2012b) Ecology and hybridization potential of two sympatric metallophytes, the narrow endemic Crepidorhopalon perennis (Linderniaceae) and its more widespread congener C. tenuis. Biotropica 44: 454-462. http://dx.doi.org/10.1111/ j.1744-7429.2011.00845.x

Grace J.B., Harrison S., Damschen E.I. (2011) Local richness along gradients in the Siskiyou herb flora: R. H. Whittaker revisited. Ecology 92: 108-120. http://dx.doi.org/10.1890/09-2137.1

Harrison S., Inouye B.D. (2002) High $\beta$ diversity in the flora of Californian serpentine 'islands'. Biodiversity and Conservation 11: 1869-1876. http://dx.doi.org/10.1023/A:1020357904064

Harrison S.P., Rajakaruna N. (2011) Serpentine: Evolution and Ecology in a Model System. Berkeley, University of California Press.

Hastie T.J., Tibshirani R.J. (1990) Generalized additive models. London, Chapman \& Hall.

Heegaard E. (2002) The outer border and central border for speciesenvironmental relationships estimated by non-parametric generalised additive models. Ecological Modelling 157: 131-139. http://dx.doi.org/10.1016/S0304-3800(02)00191-6

Heikkinen J., Mäkipää R. (2010) Testing hypotheses on shape and distribution of ecological response curves. Ecological Modelling 221: 388-399. http://dx.doi.org/10.1016/j.ecolmodel.2009.10.030

Howard-Williams C. (1970) The ecology of Becium homblei in central Africa with special reference to metalliferous soils. Journal of Ecology 58: 745-763. http://dx.doi.org/10.2307/2258533
Howard-Williams C. (1971) Morphological variation between isolated populations of Becium homblei (De Wild.) Duvign \& Plancke growing on heavy metal soils. Vegetation 23: 141-151. http://dx.doi.org/10.1007/BF02350619

ICMM (2006) Good Practice Guidance for Mining and Biodiversity. London, ICMM.

Jacobi C.M., do Carmo F.F., Vincent R.C., Stehmann J.R. (2007) Plant communities on ironstone outcrops: a diverse and endangered Brazilian ecosystem. Biodiversity and Conservation 16: 2185-2200. http://dx.doi.org/10.1007/s10531-007-9156-8

Kabala C., Singh R.R. (2001) Fractionation and mobility of copper, lead, and zinc in soil profiles in the vicinity of a copper smelter. Journal of Environmental Quality 30: 485-492. http://dx.doi. org/10.2134/jeq2001.302485x

Kazakou E., Dimitrakopoulos P.G., Baker A.J.M., Reeves R.D., Troumbis A.Y. (2008) Hypotheses, mechanisms and trade-offs of tolerance and adaptation to serpentine soils: from species to ecosystem level. Biological Reviews 83: 495-508. http:// dx.doi.org/10.1111/j.1469-185X.2008.00051.x

Keddy P.A. (2007) Plant and vegetation. Origins, process, consequences. Cambridge, Cambridge University Press. http://dx.doi. org/10.1017/CBO9780511812989

Kruckeberg A.R. (1984) California serpentines: flora, vegetation, geology, soils, and management problems. Berkeley, University of California Press.

Lakanen E., Erviö R. (1971) A comparaison of eight exctractants for the determination of plant available micronutrients in soils. Acta Agralia Fennica 123: 223-232.

Lazarus B.E., Richards J.H., Claassen V.P., O’Dell R.E., Ferrell M.A. (2011) Species specific plant-soil interactions influence plant distribution on serpentine soils. Plant and Soil 342: 327 344. http://dx.doi.org/10.1007/s11104-010-0698-2

Lepš J., Šmilauer P. (1999) Multivariate Analysis of Ecological Data. České Budějovice, Faculty of Biological Sciences, University of South Bohemia.

Macnair M.R., Gardner M. (1998) The evolution of edaphic endemics In: Howard D.J., Berlocher S.H. (eds) Endless forms, species and speciation: 157-151. New York, Oxford University Press.

Malaisse F., Baker A.J.M., Ruelle S. (1999) Diversity of plant communties and leaf heavy metal content at Luiswishi copper/cobalt mineralization, Upper Katanga, Dem. Rep. Congo. Biotechnologie Agronomie Société et Environnement 3: 104-114.

Malaisse F., Brooks R.R. (1982) Colonisation of modified metalliferous environments in Zaïre by the copper flower Haumaniastrum katangense. Plant and Soil 64: 289-293. http://dx.doi. org/10.1007/BF02184264

Malaisse F., Brooks R.R., Baker A.J.M. (1994) Diversity of vegetation communities in relation to soil heavy metal content at the shinkolobwe copper/cobalt/uranium mineralisation, Upper Shaba, Zaïre. Belgian Journal of Botany 127: 3-16.

Malaisse F., Colonvial-Elenkov E., Brooks R.R. (1983) The impact of copper and cobalt orebodies upon the evolution of some plant species from Upper Shaba, Zaïre. Plant Systematics and Evolution 142: 207-221. http://dx.doi.org/10.1007/BF00985899

Neaman A., Reyes L., Trolard F., Bourrié G., Sauvé S. (2009) Copper mobility in contaminated soils of the Puchuncavi valley, central Chile. Geoderma 150: 359-366. http://dx.doi. org/10.1016/j.geoderma.2009.02.017

O’Dell R.E., James J.J., Richards J.H. (2006) Congeneric serpentine and nonserpentine shrubs differ more in leaf $\mathrm{Ca}: \mathrm{Mg}$ than in tolerance of low N, low P, or heavy metals. Plant and Soil 280: 49-64. http://dx.doi.org/10.1007/s11104-005-3502-y 
O'Dell R.E., Classen V.P. (2011) Restoration and revegetation of harsh soils In: Harrison S.P., Rajakaruna N. (eds) Serpentine: The evolution and ecology of a model system. Berkeley, University of California Press. http://dx.doi.org/10.1525/california/9780520268357.003.0018

O'Dell R.E., Rajakaruna N. (2011) Intraspecific variation, adaptation, and evolution In: Harrison S.P., Rajakaruna N, (eds) Serpentine: The evolution and ecology in a model system: 97-137. Berkeley, University of California Press. http://dx.doi. org/10.1525/california/9780520268357.003.0005

Odum W. (1988) Comparative ecology of tidal freshwater and salt marshes. Annual Review of Ecology and Systematics 19: 147176. http://dx.doi.org/10.1146/annurev.es.19.110188.001051

Oksanen J.F. (2010) Multivariate analysis of ecological communities in R: vegan tutorial [Tutorial document]. Available with the program at http://vegan.r-forge.r-project.org/

Paton A.J., Brooks R.R. (1996) A re-evaluation of Haumaniastrum species as geobotanical indicators of copper and cobalt. Journal of Geochemical Exploration 56: 37-45. http://dx.doi. org/10.1016/0375-6742(95)00048-8

Poore M.E.D. (1955) The use of phytosociological methods in ecological investigations: I. The Braun-Blanquet system. Journal of Ecology 43: 226-244. http://dx.doi.org/10.2307/2257132

Pope T., Harris T.B., Rajakaruna N. (2010) Vascular plants of adjacent serpentine and granite outcrops on the Deer Isles, Maine, USA. Rhodora 112: 105-141. http://dx.doi.org/10.3119/09-02.1

Rajakaruna N. (2004) The edaphic factor in the origin of species. International Geology Review 46: 471-478. http://dx.doi. org/10.2747/0020-6814.46.5.471

Saad L., Parmentier I., Colinet G., Malaisse F., Faucon M.-P., Meerts P., Mahy G. (2012) Investigating the vegetation-soil relationships on the copper-cobalt rock outcrops of Katanga (D. R. Congo), an essential step in a biodiversity conservation plan. Restoration Ecology 20: 405-415. http://dx.doi.org/10.1111/ j.1526-100X.2011.00786.x

Silvertown J. (2004) Plant coexistence and the niche. Trends in Ecology and Evolution 19: 605-611. http://dx.doi.org/10.1016/j. tree.2004.09.003

Springer U., Klee J. (1954) Prüfung der Leistungsfähigkeit von einigen wichtigeren Verfahren zur Bestimmung des Kohlenstoffs mittels Chromschwefelsäure sowie Vorschlag einer neuen Schnellmethode. Zeitschrift für Pflanzenernährung, Düngung, Bodenkunde 64: 1-26. ter Braak C.J.F., Šmilauer P. (2002) CANOCO reference manual and CanoDraw for Windows. User's guide: software for $\mathrm{Ca}-$ nonical Community Ordination, v. 4.5. Ithaca, Microcomputer Power.

Tsiripidis I., Papaioannou A., Sapounidis V., Bergmeier E. (2010) Approaching the serpentine factor at a local scale - a study in an ultramafic area in Northern Greece. Plant and Soil 329: 35 50. http://dx.doi.org/10.1007/s11104-009-0132-9

van der Maarel E. (2005) Vegetation ecology. Oxford, Blackwell.

Violle C., Jiang L. (2009) Towards a trait-based quantification of species niche. Journal of Plant Ecology 2: 87-93. http://dx.doi. org/10.1093/jpe/rtp007

Vivian-Smith G. (1997) Microtopographic heterogeneity and floristic diversity in experimental wetland communities. Journal of Ecology 85: 71-82. http://dx.doi.org/10.2307/2960628

Whiting S.N., Reeves R.D., Baker A.J.M. (2002) Mining, metallophytes and land reclamation. Mining Environmental Management 10: 11-16.

Whiting S.N., Reeves R.D., Richards D., Johnson M.S., Cooke J.A., Malaisse F., Paton A., Smith J.A.C., Angle J.S., Chaney R.L., Ginocchio R., Jaffre T., Johns R., McIntyre T., Purvis O.W., Salt D.E., Schat H., Zhao F.J., Baker A.J.M. (2004) Research priorities for conservation of metallophyte biodiversity and their potential for restoration and site remediation. Restoration Ecology 12: 106-116. http://dx.doi.org/10.1111/j.10612971.2004.00367.x

Yoshida M., Kokonyangi J., Batumike J. (2004) The Central Africa copperbelt in Southestern Democratic Republic of Congo: IGCP-450 field workshop on proterozoic sediment-hosted base metal deposits of West Gondwana. Gondwana Research (Gondwana Newsletter Section) 7: 640-643.

Yost J.M., Barry T., Kay K.M., Rajakaruna N. (2012) Edaphic adaptation maintains the coexistence of two cryptic species on serpentine soils. American Journal of Botany 99: 890-897. http://dx.doi.org/10.3732/ajb.1100521

Manuscript received 29 Oct. 2012; accepted in revised version 14 May 2013.

Communicating Editor: Elmar Robbrecht. 